Journal of

Molecular Microbiology

and Biotechnology

\title{
The State of RT-Quantitative PCR: Firsthand Observations of Implementation of Minimum Information for the Publication of Quantitative Real-Time PCR Experiments (MIQE)
}

\author{
Sean C. Taylor ${ }^{\mathrm{a}}$ Eli M. Mrkusich ${ }^{\mathrm{b}}$ \\ ${ }^{a}$ Bio-Rad Laboratories Canada, Mississauga, Ont., Canada; ${ }^{b}$ Bio-Rad Laboratories Pacific, Sydney, N.S.W., Australia
}

\section{Key Words}

RT-quantitative PCR · Quantitative PCR · Minimum information for the publication of quantitative real-time PCR experiments (MIQE) • Experimental design

\begin{abstract}
In the past decade, the techniques of quantitative PCR (qPCR) and reverse transcription (RT)-qPCR have become accessible to virtually all research labs, producing valuable data for peerreviewed publications and supporting exciting research conclusions. However, the experimental design and validation processes applied to the associated projects are the result of historical biases adopted by individual labs that have evolved and changed since the inception of the techniques and associated technologies. This has resulted in wide variability in the quality, reproducibility and interpretability of published data as a direct result of how each lab has designed their RTqPCR experiments. The 'minimum information for the publication of quantitative real-time PCR experiments' (MIQE) was published to provide the scientific community with a consistent workflow and key considerations to perform qPCR experiments. We use specific examples to highlight the serious negative ramifications for data quality when the MIQE guidelines are not applied and include a summary of good and poor practices for RT-qPCR.

(c) 2013 S. Karger AG, Basel
\end{abstract}

\section{A Method for Consistency}

The application of inconsistent experimental design and techniques to quantitative PCR (qPCR) experiments has resulted in the publication of artifactual qPCR data with potentially misleading conclusions [Bustin 2010; Bustin et al. 2009b], leading to the retraction of high-profile papers [Böhlenius et al. 2007; Retraction, 2010]. This situation is further revealed in the Materials and Methods sections of many publications, where it is evident that primers and/or probes were not validated or the associated sequences were not reviewed for competing sequence homology [Wang et al., 2012]. Finally, a large number of published articles with findings that hinge on reverse transcription (RT)-qPCR data report that normalization was performed using a single reference gene untested for stability such as GAPDH, $\beta$-actin, tubulin or 18S RNA [Barber et al., 2005; Jacob et al., 2013; Rhinn et al., 2008; Schmittgen and Zakrajsek, 2000; Thellin et al., 1999; Yang et al., 2012].

Teaching and practicing qPCR according to a well-defined methodology that will ensure quality data has been a central theme in recent years and especially since the inception of the 'minimum information for the publication of quantitative real-time PCR experiments' (MIQE) guidelines [Taylor et al., 2010]. Adherence to key components of a robust experimental design, including best practices in sample preparation, extraction and storage,

\begin{tabular}{|c|c|}
\hline KARGER & $\begin{array}{l}\text { (c) } 2013 \text { S. Karger AG, Basel } \\
1464-1801 / 13 / 0241-0046 \$ 38.00 / 0\end{array}$ \\
\hline $\begin{array}{l}\text { E-Mail karger@karger.com } \\
\text { www.karger.com/mmb }\end{array}$ & $\begin{array}{l}\text { This is an Open Access article licensed under the terms of the } \\
\text { Creative Commons Attribution-NonCommercial 3.0 Un- } \\
\text { ported license (CC BY-NC) (www.karger.com/OA-license), } \\
\text { applicable to the online version of the article only. Distribu- } \\
\text { tion permitted for non-commercial purposes only. }\end{array}$ \\
\hline
\end{tabular}

Sean C. Taylor

Bio-Rad Laboratories Canada, Inc. 1329 Meyerside Drive

Mississauga, ON L5T1C9 (Canada)

E-Mail sean_taylor@biorad.com 
Table 1. Producing excellent qPCR data: do's

\begin{tabular}{|c|c|c|c|c|}
\hline Step & Description & Theme & Substeps & What to do \\
\hline \multirow[t]{2}{*}{1} & $\begin{array}{l}\text { Sample extraction } \\
\text { and storage }\end{array}$ & $\begin{array}{l}\text { quickly and } \\
\text { reproducibly }\end{array}$ & tissue removal & stagger treatments for consistent treatment times \\
\hline & & & & $\begin{array}{l}\text { for cell culture, wash plates, add lysis buffer from RNA extraction } \\
\text { kit directly to the plate and generate a stable homogenate by } \\
\text { scraping cells and pipetting up and down, then freeze }\end{array}$ \\
\hline \multirow[t]{2}{*}{2} & RNA extraction & $\begin{array}{l}\text { batch samples, } \\
\text { RNase-free, fully } \\
\text { frozen, use a kit }\end{array}$ & preparing the bench & $\begin{array}{l}\text { use RNase-free tips, tubes on a clean bench, pipettes and gloves } \\
\text { that have been cleaned with an RNAse cleaning product such as } \\
\text { ZAP or RNAse Away }\end{array}$ \\
\hline & & & $\begin{array}{l}\text { removing samples } \\
\text { from the }-80^{\circ} \mathrm{C} \\
\text { freezer }\end{array}$ & $\begin{array}{l}\text { remove a batch of samples to extract at the same time; all samples } \\
\text { should be kept on dry ice or dry ice mixed with ethanol until RNA } \\
\text { extraction }\end{array}$ \\
\hline \multirow[t]{2}{*}{3} & $\begin{array}{l}\text { Testing the RNA } \\
\text { samples }\end{array}$ & purity and quality & $\begin{array}{l}\text { purity test to limit } \\
\text { protein } \\
\text { contaminants }\end{array}$ & $\begin{array}{l}\text { test the DNAse-digested, column-purified RNA samples on a } \\
\text { spectrophotometer to ensure an } \mathrm{OD}_{260 / 280} \text { of } 1.8 \text { or higher }\end{array}$ \\
\hline & & & $\begin{array}{l}\text { quality test to avoid } \\
\text { using degraded RNA }\end{array}$ & $\begin{array}{l}\text { after the purity test, run the RNA samples on a formaldehyde } \\
\text { denaturing agarose gel }(28 \mathrm{~S} / 18 \mathrm{~S} \text { ribosomal RNA ratio of at least } 1) \\
\text { or if samples are precious and limiting on an automated } \\
\text { electrophoresis instrument like the Experion }{ }^{\mathrm{TM}} \text { to ensure that they } \\
\text { are not degraded (RQI number of at least } 7.0)\end{array}$ \\
\hline \multirow[t]{2}{*}{4} & $\begin{array}{l}\text { Reverse } \\
\text { transcription }\end{array}$ & $\begin{array}{l}\text { use same input } \\
\text { RNA }\end{array}$ & $\begin{array}{l}\text { normalize } \\
\text { concentrations }\end{array}$ & $\begin{array}{l}\text { normalize all extracted RNA samples to the same approximate } \\
\text { concentration and then add the same volume to the RT reaction }\end{array}$ \\
\hline & & & use a good kit & $\begin{array}{l}\text { use a good RT kit such as iScript }{ }^{\mathrm{TM}} \text { that contains a robust enzyme } \\
\text { mix over a broad dynamic range of RNA concentrations }\end{array}$ \\
\hline \multirow{2}{*}{6} & & & $\begin{array}{l}\text { run qPCR product } \\
\text { on a gel }\end{array}$ & $\begin{array}{l}\text { running a gel and potentially sequencing the amplicon is good } \\
\text { practice during primer validation to ensure primer specificity }\end{array}$ \\
\hline & & & $\begin{array}{l}\text { standard curve to } \\
\text { test efficiency, } \\
\text { dynamic range and } \\
\text { determine dilution } \\
\text { of unknowns }\end{array}$ & $\begin{array}{l}\text { for each primer pair, perform an } 8 \text {-point dilution series of a } \\
\text { pooled cDNA sample from across the treatment conditions as } \\
\text { follows: high expressors, } 8 \text {-fold; medium expressors, } 4 \text {-fold; } \\
\text { low expressors, } 2 \text {-fold }\end{array}$ \\
\hline \multirow[t]{2}{*}{7} & $\begin{array}{l}\text { Reference gene } \\
\text { validation }\end{array}$ & $\begin{array}{l}\text { source literature } \\
\text { and test with } \\
\text { GeNorm and } \\
\text { NormFinder }\end{array}$ & $\begin{array}{l}\text { source literature for } \\
\text { stable reference } \\
\text { genes }\end{array}$ & $\begin{array}{l}\text { use Google Scholar and search for 'qPCR reference gene genorm } \\
\text { [your organism/tissue of interest]'; derive a list of } 6-10 \text { targets } \\
\text { from the literature to test their stability in your samples }\end{array}$ \\
\hline & & & $\begin{array}{l}\text { test the } 6 \text { potential } \\
\text { targets using } \\
\text { GeNorm and pick } \\
\text { the } 2 \text { or } 3 \text { most } \\
\text { stable for } \\
\text { normalization }\end{array}$ & $\begin{array}{l}\text { an initial qPCR experiment with the validated reference gene } \\
\text { primers and selected cDNA samples from each treatment should } \\
\text { be run; CFX Manager from Bio-Rad incorporates GeNorm to } \\
\text { determine the most stable targets that vary minimally in their } \\
\text { expression over the treatment conditions }\end{array}$ \\
\hline
\end{tabular}

RQI = RNA Quality Indicator. 
RNA isolation and purification, RT, qPCR with validated primers and normalization with stable reference targets, will eliminate erroneous data.

To address the challenge of obtaining precise, reproducible and accurate results from qPCR experiments, a group of scientists came together in 2009 to develop a set of guidelines known as MIQE [Bustin et al., 2009a]. MIQE guidelines were the community's first attempt to map out the methodology and key validation criteria required to perform qPCR experiments. Since their publication, a number of papers have supported the need for a consistent and rigorous methodology to ensure the publication of accurate results [De Keyser et al., 2013; Dooms et al., 2013; Lanoix et al., 2012; Taylor et al., 2010, 2011].

Given their framework for generating robust qPCR data, it is surprising that the MIQE standards have not been embraced more widely in practice. Since 2010, more than 23,000 papers featuring qPCR data have been published, but only approximately $5 \%$ of these cite the MIQE guidelines (Google Scholar search for 'qPCR' after 2010). This low citation rate suggests that the vast majority of labs have either not been informed of the guidelines, have chosen to ignore them or believe that they do not apply to their experiments based on historical knowledge and biases that may date back to the early days of the technique.

\section{MIQE: A Defined Methodology for Reliable, Consistent Data}

The best practices for gene expression experiments as outlined by the MIQE criteria provide a simple and practical road map for scientists to navigate through the design of RTqPCR experiments to obtain the highest-quality data and avoid common pitfalls in experimental design and execution (table 1). Alternatively, by skipping key steps from the MIQE guidelines, data will likely still be generated but can result in irreproducible and incorrect conclusions (table 2).

\section{Sample Extraction and Storage: Freeze Tissue Immediately after Sample Extraction and Lyse Cells Directly in the Plate}

The methods for cell and tissue culture sample extraction may vary significantly from lab to lab. With adherent cells, some groups first trypsinize, scrape the plate and transfer the cells to tubes. This is followed by centrifugation to pellet the cells and RNA extraction. Other researchers wash the cells on the plate, add RNA extraction buffer directly to the plate and then scrape the plate to form a stable homogenate. For tissue samples, some labs surgically remove tissue from animals and weigh the samples at room temperature. They then slice the tissue and transfer it into tubes, all at room temperature, and finally freeze the samples at $-80^{\circ} \mathrm{C}$. Other labs immediately flash-freeze the animal tissue in liquid nitrogen, transfer it into tubes on dry ice and store it at $-80^{\circ} \mathrm{C}$. These different sample extraction and storage methods can yield vastly different results because the transcriptome is affected by each sample manipulation and can change very quickly in response to chemical and environmental treatments [Huang et al., 2013; Viertler et al., 2012]. Rigorous and reproducible methodology is achieved by halting transcription as soon as possible after sample collection. This ensures that differences recorded between bioreplicates in response to experimental treatments are due to treatment and not an artifact of sample handling.

\section{RNA Isolation: Maintain the Cold Chain with Frozen Samples prior to RNA Extraction}

Keeping tissue frozen until homogenization in a solution containing RNase inhibitors ensures consistent results by preventing inconsistent thawing of samples, which leads to differential RNA degradation [Botling et al., 2009; Huang et al., 2013; Kirschner et al., 2013]. Some labs remove tissue samples from $-80^{\circ} \mathrm{C}$ storage, transport them on blue ice and then proceed to homogenize samples and extract the RNA using a wide variety of techniques, during which the samples may begin to thaw prior to RNA extraction. Others place the sample tubes on dry ice and then grind the tissue to a powder in a mortar under liquid nitrogen before adding the RNA extraction buffer. There are many methodologies, reagents and instrument technologies for tissue disruption and homogenization for both protein and nucleic acid extraction. The goal is to convert the sample into a uniform, stable homogenate in a highly reproducible manner while preventing as much as possible any degradation and transcriptional changes from the $-80^{\circ} \mathrm{C}$ freezer through homogenization.

\section{RNA Purification and Analysis: Test RNA Sample Purity and Quality}

After RNA extraction, most labs measure the optical density $(\mathrm{OD})_{260 / 280}$ and $\mathrm{OD}_{260 / 230}$ to quantify the amount of total RNA and to ensure the sample meets
Taylor/Mrkusich 
Table 2. Producing excellent qPCR data: don'ts

\begin{tabular}{|c|c|c|c|}
\hline Step & Description & What to avoid & Data ramifications \\
\hline \multirow[t]{2}{*}{1} & $\begin{array}{l}\text { Sample extraction and } \\
\text { storage }\end{array}$ & $\begin{array}{l}\text { sacrificing animals at the same } \\
\text { time before tissue extraction }\end{array}$ & $\begin{array}{l}\text { poor biological variability and large error bars from transcriptional } \\
\text { variability caused by inaccurate treatment times in mortality and } \\
\text { variability in timing of removal of tissue from deceased animals }\end{array}$ \\
\hline & & $\begin{array}{l}\text { trypsinizing, collecting and } \\
\text { centrifuging cells before adding } \\
\text { lysis buffer }\end{array}$ & $\begin{array}{l}\text { erroneous gene expression data caused by excessive handling of cells } \\
\text { prior to homogenization }\end{array}$ \\
\hline \multirow[t]{3}{*}{2} & RNA extraction & $\begin{array}{l}\text { using regular tips or tubes that } \\
\text { have been exposed to the lab }\end{array}$ & $\begin{array}{l}\text { rapid digestion of extracted RNA leading to variable and high Cq } \\
\text { values }\end{array}$ \\
\hline & & $\begin{array}{l}\text { placing samples on blue ice, which } \\
\text { results in thawing and exposure to } \\
\text { RNase prior to } \\
\text { RNA extraction }\end{array}$ & $\begin{array}{l}\text { lysis of tissue prior to RNA extraction from freeze to thaw cycle } \\
\text { causing high variability in degradation between samples }\end{array}$ \\
\hline & & $\begin{array}{l}\text { homogenizing tissue at room } \\
\text { temperature with a procedure } \\
\text { yielding nonuniform homogenate }\end{array}$ & $\begin{array}{l}\text { risk of variability in RNA extraction, potential partial digestion of } \\
\text { RNA and lower yield potentially resulting in variable results and Cq } \\
\text { values }\end{array}$ \\
\hline \multirow[t]{2}{*}{3} & $\begin{array}{l}\text { Testing the RNA } \\
\text { samples }\end{array}$ & $\begin{array}{l}\text { accepting } \mathrm{OD}_{260 / 280} \\
\text { values below } 1.8\end{array}$ & $\begin{array}{l}\text { variable and higher Cq values from protein contaminant inhibition } \\
\text { of the RT and qPCR reactions }\end{array}$ \\
\hline & & not testing the RNA quality & $\begin{array}{l}\text { degraded RNA samples will result in artifactual and uninterpretable } \\
\text { results giving large variability in Cq values between samples }\end{array}$ \\
\hline 4 & Reverse transcription & $\begin{array}{l}\text { adding different RNA amounts to } \\
\text { the RT reaction }\end{array}$ & $\begin{array}{l}\text { wide variability in Cq values caused by differences in the RT reaction } \\
\text { from variable RNA input can dramatically alter the resulting cDNA }\end{array}$ \\
\hline 5 & Primer design & $\begin{array}{l}\text { using primer sequences } \\
\text { from the literature or websites } \\
\text { without validation }\end{array}$ & $\begin{array}{l}\text { it is not uncommon that published primer sequences are either } \\
\text { incorrect sequences or correct sequences for the wrong target; check } \\
\text { all sequences using software tools to save weeks of troubleshooting }\end{array}$ \\
\hline \multirow[t]{3}{*}{6} & Primer validation & $\begin{array}{l}\text { running qPCR experiments } \\
\text { at predicted annealing } \\
\text { temperatures from primer design } \\
\text { software without wet chemistry } \\
\text { validation }\end{array}$ & $\begin{array}{l}\text { samples used for qPCR may contain contaminants and chemicals } \\
\text { that deviate from the predicted annealing temperature from software } \\
\text { resulting in high and potentially variable Cq and artifactual data }\end{array}$ \\
\hline & & $\begin{array}{l}\text { assuming that a single } \\
\text { melt curve peak means that } \\
\text { the predicted product has } \\
\text { been amplified }\end{array}$ & months of wasted work studying an artifact \\
\hline & & $\begin{array}{l}\text { assuming primers are } \\
\text { validated with good efficiency and } \\
\text { diluting all samples by } \\
\text { a standard dilution (i.e. } 10 \text {-fold) } \\
\text { for all targets }\end{array}$ & $\begin{array}{l}\text { if samples are not diluted such that they amplify with Cq values in } \\
\text { the efficient range of the standard curve, the gene expression data } \\
\text { produced can be an artifact of nonefficient amplification }\end{array}$ \\
\hline \multirow[t]{2}{*}{7} & $\begin{array}{l}\text { Reference gene } \\
\text { validation }\end{array}$ & $\begin{array}{l}\text { trusting without independent } \\
\text { validation a peer recommended } \\
\text { reference gene target }\end{array}$ & $\begin{array}{l}\text { since reference gene targets are used to normalize the data between } \\
\text { samples, the resulting normalized, relative gene expression data will } \\
\text { be directly affected by changes in the regulation of the reference gene } \\
\text { as opposed to the target gene }\end{array}$ \\
\hline & & $\begin{array}{l}\text { using the usual suspects } \\
\text { as reference gene targets including } \\
\text { GAPDH, } \beta \text {-actin, tubulin and } 18 \mathrm{~S} \\
\text { RNA without confirming stability }\end{array}$ & \\
\hline
\end{tabular}


the minimal purity criteria with respect to protein and chemical contamination (minimum acceptable OD values of 1.8 and 2.0, respectively). Samples with lower OD values typically contain higher levels of contaminants that can inhibit both the RT and qPCR reactions, resulting in artificially high and variable quantification cycle (Cq) values and imprecise quantification. In our experience, a test that most labs do not perform is an RNA quality assessment to ensure that samples are not degraded, as RNA degradation can occur even when the utmost care is taken with sample handling [Huang et al., 2013]. RNA sample quality can be measured by visualizing extracted fragment sizes on a denaturing formaldehyde-agarose gel or by using more sensitive and precise instrumentation such as the Experion ${ }^{\mathrm{TM}}$ automated electrophoresis system from Bio-Rad or the Bioanalyzer ${ }^{\mathrm{TM}}$ from Agilent. As with purity, RNA sample quality is directly correlated with altered Cq values, where a degraded sample can give significantly higher Cq values than an intact sample [Huang et al., 2013; Taylor et al., 2011]. Furthermore, RNA quality has been shown to directly affect reference gene variability and the significance of differential gene expression data [Vermeulen et al., 2011].

\section{RT: Normalize Input RNA}

The RT reaction is a key step in sample processing. RT priming strategy, dynamic range and RT enzyme type are all important to ensure mRNA expression levels are accurately represented in the resulting cDNA [Jacob et al., 2013]. Transcription of both low- and high-expression targets, and thus a wide linear dynamic range for the RT step, is required for accurate representation of these expression levels in the final data. Performing a serial dilution of the input RNA to determine the linear dynamic range of reverse transcribed cDNA will reveal the amount of RNA required for the RT step to ensure consistent coverage of all targets in the sample. Care should be taken to normalize the amount of input RNA for RT with consistency in kit selection and protocol to ensure that all RNA samples are treated similarly. If different amounts of input RNA are used between samples, variable levels of contaminants can be introduced that may inhibit the RT reaction in an unpredictable manner, resulting in variable RNA coverage and cDNA output. The resulting gene expression results are often uninterpretable; therefore, care should be taken to ensure consistent loading of
RNA. The hallmarks of a good RT kit include a mix of random hexamers and oligo dTs to obtain the best coverage of the RNA with high fidelity and robust reverse transcriptase containing $\mathrm{RNase} \mathrm{H}$ to digest the copied template as the transcript is transcribed. A single-step kit in which RNA is added to a single RT mix containing a combination of the RT and hot-start qPCR mixes in one reaction can help minimize technical variability among samples.

\section{Primer Validation: Always Validate Primer Sequences}

Many researchers do not validate their primers because the sequences were sourced directly from peerreviewed literature, obtained from prior lab members or directly from vendors as 'off-the-shelf' assays. This practice presumes that the scientists who originally published the GPCR data correctly validated their primers in the same cells and/or tissues as in the current study set, but this may not be the case [Wang et al., 2012]. Many 'off-the-shelf' assays have only been designed in silico and are often not provided with any validation data, which may preclude MIQE compliance [Bustin et al., 2011]. Rather than make this presumption, labs should validate all primers - including those used by previous authors and vendors - for primer concentration, annealing temperature, specificity and efficiency, with further validation for linear dynamic range with a standard curve from a representative sample [Mikeska and Dobrovic, 2009; Taylor et al., 2010, 2011]. Ideally, validation should be performed on a qPCR instrument that is enabled with thermal gradient capability and has the sensitivity to detect 10 or fewer copies of the target sequence. The ramifications of poorly validated primers for annealing temperature and efficiency with standard curves are inaccurate $\mathrm{Cq}$ values and gene expression results leading to incorrect and even opposite conclusions [Opel et al., 2010]. Because primers require independent validation for each sample type (for example, brain versus heart tissue) and also for each RNA extraction method (such as TRIzol versus a kitbased method), an 8-point standard curve of the appropriate fold dilution of cDNA using a good-quality qPCR supermix is recommended. Only thorough primer validation will ensure that the $\mathrm{qPCR}$ reaction conditions are optimal for a given sample set and that the samples are diluted such that reaction efficiency is optimal for each target.
Taylor/Mrkusich 


\section{Reference Gene Selection: Choose a Target by Testing Stability between Experimental Conditions}

Since the release of the MIQE guidelines, a number of published articles have described the effect of improper reference gene selection on the final data [Barber et al., 2005; Jacob et al., 2013; Lanoix et al., 2012; Rhinn et al., 2008; Schmittgen and Zakrajsek, 2000; Taylor et al., 2011; Thellin et al., 1999; Yang et al., 2012]. Normalization of qPCR data with a poorly selected reference gene can dramatically alter the final results to the extent that opposite conclusions can be obtained when compared to results with normalization with stable reference genes. Many labs performing qPCR on a regular basis have only normalized samples to a single, unvalidated reference gene that they have used for all qPCR projects over many years. The list of potential reference genes has increasingly been chosen from publications referring to the tools GeNorm and NormFinder for reference gene stability. A compilation of at least 6-10 separate reference gene candidate primer pairs should be validated as described in the previous section and then tested for stability in samples derived from each of the experimental conditions using GeNorm, NormFinder and BestKeeper [Jacob et al., 2013; Lanoix et al., 2012]. The result of poor reference gene selection for the final data and conclusions is now well documented and has called into question the validity of publications that have only used a single unvalidated reference gene [Barber et al., 2005; Jacob et al., 2013; Rhinn et al., 2008; Schmittgen and Zakrajsek, 2000; Thellin et al., 1999; Williams, 2012; Yang et al., 2012].

\section{Conclusions}

Although some labs continue to argue that MIQE criteria are simply 'guidelines' that do not necessarily need to be followed, there are very good reasons to adopt the best practices outlined here as well as other elements of the guidelines. While some forethought is required for planning an MIQE-guided experiment, the benefits of following these guidelines help ensure robust, reliable and reproducible gene expression results for publication and provide the confidence that the data, interpretations and conclusions will hold up to reader scrutiny.

\section{References}

Barber RD, Harmer DW, Coleman RA, Clark BJ: GAPDH as a housekeeping gene: analysis of GAPDH mRNA expression in a panel of 72 human tissues. Physiol Genomics 2005;21: 389-395.

Böhlenius H, Eriksson S, Parcy F, Nilsson O: Retraction - The mRNA of the Arabidopsis gene FT moves from leaf to shoot apex and induces flowering. Science 2007;316:367.

Botling J, Edlund K, Segersten U, Tahmasebpoor S, Engström M, Sundström M, Malmström PU, Micke P: Impact of thawing on RNA integrity and gene expression analysis in fresh frozen tissue. Diagn Mol Pathol 2009;18:44-52.

Bustin SA: Why the need for qPCR publication guidelines? The case for MIQE. Methods 2010;50:217-226.

Bustin SA, Benes V, Garson JA, Hellemans J, Huggett J, Kubista M, Mueller R, Nolan T, Pfaffl MW, Shipley GL, Vandesompele J, Wittwer CT: The MIQE guidelines: minimum information for publication of quantitative real-time PCR experiments. Clin Chem 2009a;55:611-622.

Bustin SA, Benes V, Garson JA, Hellemans J, Huggett J, Kubista M, Mueller R, Nolan T, Pfaffl MW, Shipley GL, Vandesompele J, Wittwer CT: Primer sequence disclosure: a clarification of the MIQE guidelines. Clin Chem 2011;57:919-921.
Bustin SA, Vandesompele J, Pfaffl M: Standardization of qPCR and RT-qPCR. Gen Eng Biotechnol News 2009b;29.

De Keyser E, Desmet L, Van Bockstaele E, De Riek J: How to perform RT-qPCR accurately in plant species? A case study on flower colour gene expression in an azalea (Rhododendron simsii hybrids) mapping population. BMC Mol Biol 2013;14:13.

Dooms M, Chango A, Barbour E, Pouillart P, Abdel Nour AM: Improving biological relevancy of transcriptional biomarkers experiments by applying the MIQE guidelines to pre-clinical and clinical trials. Methods 2013:59:147-153.

Huang X, Baumann M, Nikitina L, Wenger F, Surbek D, Körner M, Albrecht C: RNA degradation differentially affects quantitative mRNA measurements of endogenous reference genes in human placenta. Placenta 2013; 34:544-547.

Jacob F, Guertler R, Naim S, Nixdorf S, Fedier A, Hacker NF, Heinzelmann-Schwarz V: Careful selection of reference genes is required for reliable performance of RT-qPCR in human normal and cancer cell lines. PLoS One 2013;8:e59180.

Kirschner MB, van Zandwijk N, Reid G: Cell-free microRNAs: potential biomarkers in need of standardized reporting. Front Genet 2013;4: 56.
Lanoix D, Lacasse AA, St-Pierre J, Taylor SC, Ethier-Chiasson M, Lafond J, Vaillancourt C: Quantitative PCR pitfalls: the case of the human placenta. Mol Biotechnol 2012;52:234243

Mikeska T, Dobrovic A: Validation of a primer optimisation matrix to improve the performance of reverse transcription - quantitative real-time PCR assays. BMC Res Notes 2009;2: 112.

Opel KL, Chung D, McCord BR: A study of PCR inhibition mechanisms using real time PCR. J Forensic Sci 2010;55:25-33.

Retraction - Ileal-lymphoid-nodular hyperplasia, nonspecific colitis, and pervasive developmental disorder in children. Lancet 2010;375: 445.

Rhinn H, Marchand-Leroux C, Croci N, Plotkine M, Scherman D, Escriou V: Housekeeping while brain's storming: validation of normalizing factors for gene expression studies in a murine model of traumatic brain injury. BMC Mol Biol 2008;9:62.

Schmittgen TD, Zakrajsek BA: Effect of experimental treatment on housekeeping gene expression: validation by real-time, quantitative RT-PCR. J Biochem Biophys Methods 2000; 46:69-81 
Taylor S, Buchanan M, Basik M: A MIQE case study - effect of RNA sample quality and reference gene stability on gene expression data. Bio-Rad tech note 6245, 2011.

- Taylor S, Wakem M, Dijkman G, Alsarraj M, Nguyen M: A practical approach to RTqPCR-publishing data according to the MIQE guidelines. Methods 2010;50:S1-S5.

- Thellin O, Zorzi W, Lakaye B, De Borman B, Coumans B, Hennen G, Grisar T, Igout A, Heinen E: Housekeeping genes as internal standards: use and limits. J Biotechnol 1999;75:291-295.
Vermeulen J, De Preter K, Lefever S, Nuytens J, De Vloed F, Derveaux S, Hellemans J, Speleman F, Vandesompele J: Measurable impact of RNA quality on gene expression results from quantitative PCR. Nucleic Acids Res 2011;39:e63.

Viertler C, Groelz D, Gündisch S, Kashofer K, Reischauer B, Riegman PH, Winther R, Wyrich R, Becker KF, Oelmüller U, Zatloukal $\mathrm{K}$ : A new technology for stabilization of biomolecules in tissues for combined histological and molecular analyses. J Mol Diagn 2012;14: 458-466.
Wang X, Spandidos A, Wang H, Seed B: PrimerBank: a PCR primer database for quantitative gene expression analysis, 2012 update. Nucleic Acids Res 2012;40:D1144-D1149.

Williams SCP: How reliable is real-time PCR? Biotechniques, PCR Feature, 2012.

Yang X, Hatfield JT, Hinze SJ, Mu X, Anderson PJ, Powell BC et al: Bone to pick: the importance of evaluating reference genes for RTqPCR quantification of gene expression in craniosynostosis and bone-related tissues and cells. BMC Res Notes 2012;5:222. 